HYDROLOGY IN THE UNITED STATES.

$W^{E}$ have referred on previous occasions to the very complete way in which hydrological research is carried out in the United States, and to the value of the reports that are made from time to time by the officers having charge of the works. ${ }^{1}$ We have been favoured with twenty-five further reports recently issued. The greater part of these refer to the water resources, and to the surveys being carried out by the departments in the different States. These are principally of local interest, although they contain a great deal of information useful to those engaged in water supply. Some of these reports, however, relate to matters that are of more general interest. ${ }^{2}$

Paper IIg contains an index to the hydrographic progress reports, 1888-1903, and paper 120 a review and index to papers relating to underground waters published by the United States Geological Survey, 1879-1904.

Report No. IIo, on the hydrology of the eastern United States, contains twenty-three short papers by nineteen geologists and physicists connected with the eastern section

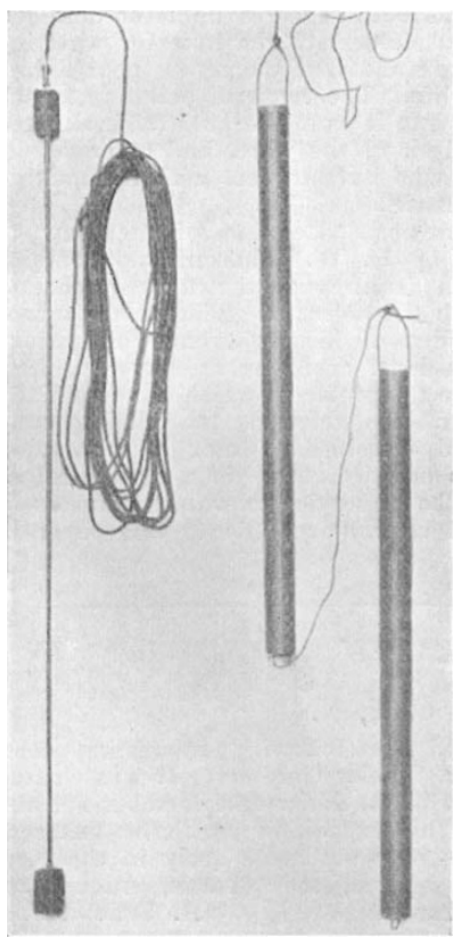

Fig. I.--Electrode and p-rfurated brass buckets used in charging wells. of this division of hydrology. The most interesting of these papers is that which relates to the methods used in measuring the velocity, direction, and quality of underground water.

The Discharge of Sewage into Porous Strata.-In one of the papers, by $\mathrm{S}$. W. Callie, is recorded the experiments made to ascertain what would be the effect of discharging town sewage into pervious strata on the water supply of the neighbourhood $\mathrm{drawn}$ from wells.

The town of Quitman derives its water supply from a well in the limestone at a depth of 123 feet from the surface. A section of the soil shows 2 feet of surface sand, 60 feet of clay, I5 feet of sand, and 43 feet of water-bearing limestone.

The authorities of the town were seriously considering the question of disposing of the town's sewage by means of deep wells into the porous strata. The writer of the paper was engaged to report as to what effect this 'would have on the water supply. For this purpose he adopted the chlorine process. Seven wells in the locality were selected for making the experiment, the water in which was found to stand at a lower level than that in which the chlorine was to be introduced. Samples were taken from these wells, and the normal amount of chlorine determined. Two tons of salt were then put into the test well in the form of solution during a period of five days. Special precautions were taken in the method of introducing the salt to ensure complete saturation of the water. The normal chlorine at the well from which the

J "Water Supply and Irrigation in the United States" (NATURE, January 7, 1904); "Relation of Rainfall to Run Off" (July 28, 1904) "Floods in the Mississippi Valley" (November 3, 1904); "Hydrology in the United States" (December 22, 3904).

" "Water Supply and Irrigation Papers," Nos. 99 to 132. (Washington: Government Printing Office, 1904-5.)

NO. I 886,1 OL. 73$]$ water supply for the town was drawn was 5.44 parts in a million. Four hours after the introduction of the salt in the test well the chlorine began to increase, reaching a maximum of 6.80 parts in twelve hours, and continued to show an excess during the five days, after which it

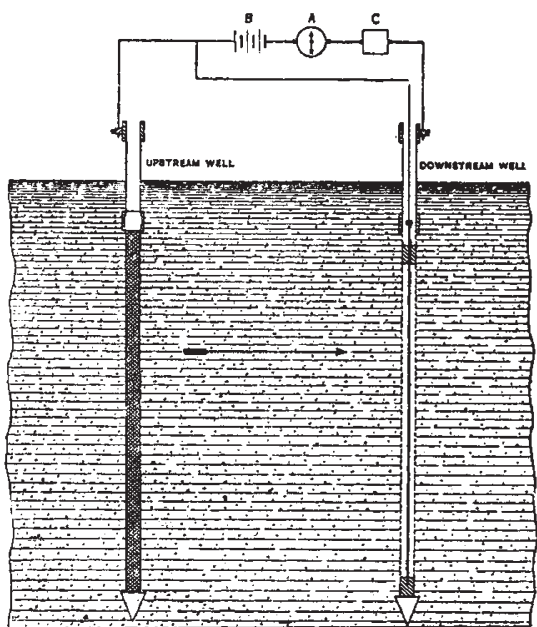

FIG. 2.-Diagram illustrating electrical method of determining the velocity of flow of ground water. The ground water is supposed to be moving in the direction of the arrow. The up-stream well is charged with an electrolyte. The gradual motion of the ground water toward the lower well and its final arrival at that well are registered by the ammeter $A$ $B$ is the battery, and $C$ a commutator clock which is used if $A$ is a recording ammeter.

gradually subsided to its normal quantity. At two of the other wells a similar excess of chlorine was found, but at the other wells no change in the character of the water took place.

The general conclusion arrived at was that if sewage were discharged into the water-bearing strata it would contaminate all the wells in the locality that had a depth of 120 feet or more, and that if the proposed scheme of the municipality had been carried out it would probably have resulted in a serious epidemic.

Measurement of Underground Currents. -A paper by Charles S. Slichter gives a description of the underfiow meter used in measuring the velocity and direction of underground water.

For the purpose of measuring the underground flow in any locality test wells are sunk consisting of $1 \frac{1}{2}$-inch or 2 -inch tubes. These pipes are in lengths of 6 feet or 7 feet, with long threads and heavy wrought nipples. The well points are 4 -feet brass jacket points of wire gauze. The tubes are driven with a ram weighing from $150 \mathrm{lb}$. to $25^{\circ} \mathrm{lb}$., the movement of the tube being aided by a water jet. Four wells were driven from 4 feet to 6 feet apart in a triangular form, one at the apex and the other three at the base of the triangle. The deeper the wells the greater the distance apart at which they were placed.

The up-stream well is charged with a strong electrolyte such as sal ammoniac, which passes down stream with the underground water to the lower wells (Fig. I). Fig. 3.-Perforator Each of the down-strem wells contains for slitting well within the well point an electrode consist- pipes. ing of a nickel brass rod $\frac{3}{6}$-inch thick by 4 feet long, insulated from the casing by wooden spools. This electrode communicates with the surface by means of rubber-covered copper wire, and connects with a recording ammeter. As the electrolyte reaches one of the downstream wells its appearance is at once recorded by the 
meter, the time occupied in passing from the upper to the lower well being thus found, and giving the rate of flow of the water.

Further details of observations of underground flow as carried out by this method are given in paper No. 112 , by Homer Hamlin, with numerous illustrations of the apparatus used.

Stove-pipe Wells.-In the same report is a paper by Charles S. Slichter on the method of sinking stovepipe wells. These consist of a riveted sheet steel starter from 15 feet to 25 feet long, made of two or three thicknesses of sheet steel with a forged steel shoe at the lower end. The rest of the casing consists of two thicknesses of sheet steel made into riveted lengths of 2 feet, one set of sections being made just so much smaller than the other as to permit them to telescope together. Each outside section overlaps the inside section $I$ foot. This casing is sunk, length by length, by hydraulic jacks, which press on the upper sections by means of a suitable head. After the well has been sunk to the required depth, a cutting knife is lowered into the well and vertical slits are cut in the casing opposite such water-bearing strata as may have been met with; a well 500 fest deep may have 400 feet of screen if circumstances justify it. The perforator is handled with 3 -inch pipe. By raising slowly on the line with hydraulic jacks, cuts are made from three-eighths to three-fourths of an inch wide, and from 6 to 12 inches long.

The well casings vary in diameter from 17 inches to I 4 inches, and are sunk to depths from 500 feet to 1400 feet, the yield of water varying from 300,000 to $3,000,000$ gallons in twenty-four hours. The cost of a 12-inch 500 feet well is about I 1 ol. for labour and rool. for materials, the drillers being paid $\mathrm{I} l$. and the labourers Ios. a day. The soil where these wells are in use consists of mountain débris, clay, gravel, sand, and boulder.

Pollution of Streams by Waste from Factories.-Paper No. 103 contains a review of the laws in operation in the different States of America for the prevention of pollution of inland waters. The broad legal principles under which anti-pollution statutes become operative are explained, and important Court decisions are quoted to show the authority upon which certain deductions in the report are founded.

In paper No. I33 the special stream pollution arising from the refuse water from the "straw board " factories is dealt with. In Indiana, Ohio, and Illinois there are several large factories engaged in making pasteboard from rye, wheat, and oat straw. For this process 40,000 gallons of water are required to wash $I$ ton of straw, and $3200 \mathrm{lb}$. of straw and $560 \mathrm{lb}$. of lime are required to make $2000 \mathrm{lb}$. of board. In an ordinary factory $2,000,000$ gallons of water are used daily, which carries with it Ig tons of straw waste and ro tons of lime. This waste generally runs into a neighbouring stream, and is the cause of a serious amount of pollution. The report of the Government Commissioner for Fisheries states that the pollution of the streams in Indiana by the refuse from the strawboard mills, oil mills, and pulp mills is greater than from any other source. The refuse from these covers the spawning beds and prevents the eggs from hatching, while it penetrates the gills of the living fish and either kills or drives them away from the streams,

The remedy is by chemical precipitation of the waste products, but it is contended that the small profit on the manufacture of strawboard does not permit of the application of the process required.

Another source of water pollution dealt with in this report arises from the overflow from the oil wells in Indiana. Around the city of Marion there are no less than seventy-five oil wells in a few square miles of territory. Upwards of 300 surface and rock wells in this area are suffering contamination from this source. The strata in this district consists of sand and gravel for about 50 feet, then clay for about 80 feet, and below this limestone. The water supply of the town and neighbourhood is derived from water in the limestone, and there is a. constant flow of underground water. Oil occurs near the top of the formation. Beneath the oil is salt water. In order to form a reservoir for the oil the limestone is entered some distance, and the most successful wells are those which are drilled deep enough to allow a large N'. I 886 , VOL. 73 ] amount of oil to collect, so as to be above the upper level of the brine. These oil wells are generally rooo feet deep, the oil rising to within 600 feet or 700 feet of the surface. When the well is bored it is "shot" with nitroglycerin, which breaks up the limestone and forms fissures and small cavities which act as reservoirs into which the oil flows. The surface effect of the shooting is the violent ejection of salt water and oil, often to the extent of thousands of gallons. The oil and salt water then sink into the soil where it is porous, and finally reach the surface zone of underground flow, where they partake of the general movement of the water toward the main line of underground drainage, and cause its pollution. The brine and oil pumped from these oil wells is discharged into a settling tank. The oil, owing to its lighter specific gravity, settles at the top and is drawn off, the brine being discharged into any neighbouring creek or stream, or is allowed to sink slowly into the ground, in either case becoming a serious source of pollution to the water supply of the neighbourhood.

Paper No. I2I relates to the pollution of Lake Champlain, by M. O. Leighton. The report was made in consequence of complaints made to the Government that the water of the lake has been rendered unfit for domestic consumption; that the usefulness of the lake for watering cattle has been destroyed; and that the refuse poured into it is destructive to fish life. The cause of pollution is due to the waste discharged into it from the pulp mills situated on its banks. The analysis of the water and other details are interesting to those who have to deal with the making of pulp and similar industries.

Paper No. 122 is entitled " Relation of the Law to Underground Waters," by D. W. Johnson, and contains an outline of the main features of the laws respecting underground waters with the object of giving to the owner of such waters some idea of his rights and obligations concerning them. Such legal decisions as serve to show the relation of the law to the problems which are essentially geological in character are referred to. Underground waters are defined and classified. Although this paper refers to United States practice, there is a great deal of information that would be of service to water engineers in this country. We shall refer more fully to this paper in a future number.

\section{THE PERCY SLADEN EXPEDITION IN H.M.S. "SEALARK" TO THE INDIAN} $O C E A N$.

HAVE just received the following interesting communication from Mr. Stanley Gardiner. It was written from Port Victoria, Seychelles, under date October 28, and is the fourth report of his expedition which he has sent home. Mr. Gardiner is expected home early in the New Year. For his earlier reports, see NATURE, August Io, October 5, and November 9. A. SEDGwick. Cambridge, December 1 .

During the ten days that the Sealark left us at Coetivy while she was coaling in the Seychelles, we as thoroughly as possible collected the animals and plants of both the land and reef. The island was higher than any we had up to that time visited, having wind-blown sand ridges and hills up to 80 feet above sea-level, arising on a flat coral reef. Although situated only about 130 miles to the south of the Seychelles Islands, the land fauna and flora are almost the same as on the islands of the Chagos Archipelago, being scarcely richer in either. The plants, of course, in the main necessarily govern the fauna, and it would appear to us that they are in their turn governed rather by the nature of the soil-coral and coral sandthan by their proximity to continental land. On the other hand, the reefs of Coetivy showed in every group of marine animals a more varied fauna than those of the Chagos, while very nearly all the species of the latter seemed to be present. The reef on the eastern, or seaward, face of the island was of a rather different character from any we had as yet seen (or from any I have seen in the Pacific), being covered with a grass-like weed, locally termed "varech." There was also on the same part a 